\title{
ЦІННІСНИЙ СКЛАДНИК ІНКЛЮЗИВНОЇ КОМПЕТЕНТНОСТІ ВЧИТЕЛЯ НОВОЇ УКРАЇНСЬКОЇ ШКОЛИ
}

\author{
Гура Т. С. \\ доктор психологічних наук, професор, \\ проректор з наукової роботи та міжнародної діяльності \\ КЗ «Запорізький обласний інститут післядипломної педагогічної освіти» \\ Запорізької обласної ради \\ вул. Незалежної України, 57А, Запоріжжя, Украӥна \\ orcid.org/0000-0002-4869-1360 \\ tatianagura16@gmail.com \\ Гура O. I. \\ доктор педагогічних наук, професор, \\ проректор з навчальної та науково-педагогічної роботи \\ Запорізький національний університет \\ вул. Жуковського, 66, Запоріжжя, Украӥна \\ orcid.org/0000-0001-6720-2481 \\ guru.olexandr@gmail.com
}

Ключові слова: інклюзивна компетентність, професійна компетентність, інклюзивне навчання, ціннісне ставлення, особа з особливими освітніми потребами.
Статтю присвячено проблемі визначення сутності інклюзивної компетентності вчителя закладу загальної середньої освіти в умовах запровадження Концепції Нової української школи. На підставі авторського інтегративного підходу інклюзивна компетентність сучасного вчителя визначена складником його цілісної професійної компетентності, складним особистісно-професійним утворенням, особливою інтегративною якістю, що забезпечує ефективність професійної діяльності фахівця із реалізації інклюзивного навчання, організації безпечного та здорового освітнього середовища, а також детермінує успішність його подальшого професійного розвитку загалом та у сфері інклюзивної освіти зокрема.

3 огляду на Рекомендації ради Європи щодо ключових компетентностей для освіти впродовж життя структура інклюзивної компетентності вчителя подана як єдність ціннісного, когнітивного та конструктивного компонентів. Серед них саме ціннісний компонент визначено системотвірним, інтегрувальним, методологічним. Він виявляється y: прийнятті педагогом цінностей філософії інклюзивної освіти; прийнятті власної інклюзивності, зумовленої усвідомленням особистої унікальності, неповторності та, відповідно, наявності особливих освітніх потреб; ціннісному ставленні до інклюзивного навчання, до проєктування та організації інклюзивного освітнього середовища; прийнятті ролі фасилітатора, проєктувальника індивідуальної освітньої траєкторії учнів; позитивній мотивації педагогічної діяльності та професійного розвитку, а також позитивному ставленні до необхідності зміни власної педагогічної діяльності, застосування нових освітніх стратегій.

Формування інклюзивної компетентності вчителя 3 урахуванням іiі багатокомпонентної, динамічної структури є складним і тривалим процесом, що вимагає комплексності та різновекторності дій. Традиційне спрямування педагогічної освіти на оволодіння вчителями спеціалізованими професійними знаннями та уміннями для розбудови інклюзивного освітнього середовища має бути переорієнтоване на 
забезпечення формування у вчителів ціннісного ставлення до інклюзії як створення умов для повноцінної участі та доступу до якісних навчальних можливостей усіх учнів відповідно до їхніх індивідуальних особливостей, а не лише дітей з особливостями психофізичного розвитку, інвалідністю. Зазначене вимагає як узгодження, врегулювання нормативноправових засад педагогічної діяльності, так і термінової зміни акцентів у професійній підготовці вчителів до інклюзивного навчання у системі вищої та післядипломної педагогічної освіти.

\title{
VALUE COMPONENT OF INCLUSIVE COMPETENCE OF THE NEW UKRAINIAN SCHOOL TEACHERS
}

\author{
Gura T. E. \\ Doctor of Psychology, Professor, \\ Vice-Rector for Research and International Work \\ Communal institution "Zaporizhzhya Regional Institute of Postgraduate Pedagogical Education" \\ of Zaporizhzhya Regional Council \\ Independent Ukraine str., 57A, Zaporizhzhia, Ukraine \\ orcid.org/0000-0002-4869-1360 \\ tatianagura16@gmail.com
}

Gura O. I.

Doctor of Pedagogy, Professor,

Vice-Rector for Educational and Scientific-Pedagogical Work

Zaporizhzhia National University

Zhukovsky str., 66, Zaporizhzhia, Ukraine

orcid.org/0000-0001-6720-2481

guru.olexandr@gmail.com

Key words: inclusive competence, professional competence, inclusive education, values, person with special educational needs.
The article is devoted to a problem of defining the essence of inclusive competence of a teacher of a general secondary education institution in the conditions of the introduction of the New Ukrainian school concept. Based on the author's integrative approach, the inclusive competence of a modern teacher is defined as a component of his holistic professional competence, complex of personal and professional education, a special integrative quality that ensures the effectiveness of professional activities in the implementation of inclusive education, organization of safe and healthy educational environment. Considering the Recommendations on Key Competences for Lifelong Learning provided by the Council of Europe, the structure of inclusive teacher competence is presented as a unity of value, cognitive and constructive components. Among them, the value component is defined as system-forming, integrative, methodological. It is reflected in: the teacher's acceptance of the values of the philosophy of inclusive education; acceptance of one's own inclusiveness, conditioned by the awareness of personal uniqueness, uniqueness and, accordingly, the presence of special educational needs; value attitude to inclusive education, to the design and organization of inclusive educational environment; accepting the role of facilitator, designer of individual educational trajectory of students; positive motivation of pedagogical activity and professional development, as well as a positive attitude to the need to change one's own pedagogical activity, application of new educational strategies. 
The formation of inclusive teacher competence, taking into consideration its multicomponent, dynamic structure, is a complex and long process that requires various and multi-vector actions. The traditional focus of pedagogical education on teachers mastering the specialized professional knowledge and skills to build an inclusive educational environment should be directed on ensuring the formation of teachers' values of inclusion as creating conditions for full participation and access to quality learning opportunities for all students according to their individual characteristics, not only children with psychophysical issues or disabilities. This requires both coordination, regulation of legal framework for pedagogical activities, and urgent change of emphasis in the training of teachers for inclusive education in the system of higher and postgraduate pedagogical education.

Постановка проблеми. Останніми роками одним 3 найголовніших напрямів розвитку сучасної освіти в Україні загалом та загальної середньої освіти зокрема $\epsilon$ запровадження інклюзивного навчання як особливої системи освітніх послуг, гарантованих державою, що базується на принципах недискримінації, врахування багатоманітності людини, ефективного залучення та включення до освітнього процесу всіх його учасників [5]. Інклюзивне навчання є головною ознакою, реальним інструментом реалізації педагогіки партнерства як ключового компонента формули Нової української школи, місія якої - допомогти розкрити та розвинути здібності, таланти і можливості кожної дитини [13]. Адже саме педагогіка партнерства відповідно до сучасного науково-педагогічного та нормативного визначення грунтується на розумінні того, що кожна людина $є$ неповторною, наділеною від природи унікальними здібностями, талантами та можливостями; а домінувальними принципами взаємодії всіх суб'єктів освітньої діяльності $є$ повага, доброзичливість і позитивне ставлення, довіра, діалогічність, розподілене лідерство, соціальне партнерство. Отже, ці два вектори реформування вітчизняної загальної середньої освіти - розвиток інклюзивного навчання та запровадження Концепції Нової української школи по суті є єдиним його напрямом, що визначає нові вимоги до професійної діяльності та професійної компетентності вчителів. Незважаючи на те, що у зарубіжній та вітчизняній психолого-педагогічній літературі за останні 10 років спостерігається значне збільшення наукових досліджень, присвячених проблемі визначення професійних вимог до вчителів у контексті інклюзивного навчання, проте і дотепер спостерігається певна невизначеність в осмисленні пріоритетів підготовки фахівців у системі вищої та післядипломної педагогічної освіти.

Наявні, на нашу думку, і значні протиріччя між загальновизнаним світовим розумінням поняття «інклюзія», що детермінує конкретні національні підходи до розбудови інклюзивного освітнього простору в різних країнах, та домінувальним в українській психолого-педагогічній спільноті i науковій літературі підходом до визначення інклюзивної освіти. Так, поняття «інклюзія», як зазначено у визначальних документах ЮНЕСКО, розуміється як: політика збільшення ступеня участі всіх громадян у соціальному житті; трансформаційний процес, який забезпечує повноцінну участь та доступ до якісних навчальних можливостей для всіх дітей, молоді та дорослих, поважаючи й оцінюючи різноманітність та усуваючи всі форми дискримінації в освіті та через неї. Термін «інклюзія» означає зобов'язання створити дошкільні навчальні заклади, школи та інші освітні установи, місця, в яких цінують та які належать кожній людині, а різноманітність розглядається як збагачення [18]. Значна ж кількість вітчизняних наукових досліджень у сфері інклюзивної освіти, а також чинних програм підготовки українських педагогів до впровадження інклюзивного навчання, всупереч нормативно визначеним у Законі України «Про освіту» поняттю «особа $з$ особливими освітніми потребами» (як така, що потребує додаткової постійної чи тимчасової підтримки в освітньому процесі 3 метою забезпечення іiі права на освіту) та відповідних понять «інклюзивне навчання», «інклюзивне освітнє середовище» та ін., присвячена передусім особливостям створення умов для навчання дітей 3 порушенням розвитку, інвалідністю (як, наприклад, [14]). Це, передусім, спричиняється і відсутністю нормативної визначеності категорій осіб 3 особливими освітніми потребами в Україні, адже в деяких чинних державних документах у сфері освіти категорія «діти 3 особливими освітніми потребами» дотепер вживається у значенні порушень психофізичного розвитку [11].

Крім того, наявним, на нашу думку, є і протиріччя між знаннєво центрованою спрямованістю вітчизняної професійної підготовки вчителів до інклюзивного навчання, що яскраво виявляється 
у змісті відповідних освітньо-професійних програм, та недостатнім рівнем прийняття педагогічною спільнотою цінностей інклюзивної освіти, про що свідчать результати багатьох досліджень, освітніх моніторингів [3; 4].

Зазначені протиріччя, своєю чергою, призводять до виникнення особливих труднощів на шляху запровадження інклюзивної освіти в Україні, подолання яких, на нашу думку, вимагає зміни акцентів у професійній підготовці вчителів до інклюзивного навчання у системі вищої та післядипломної педагогічної освіти, переосмислення сутності їхньої професійної компетентності у цьому контексті, етапів та механізмів ії розвитку.

Отже, мета статті полягає у розкритті сутності інклюзивної компетентності сучасного вчителя закладу загальної середньої освіти та визначення місця ціннісного компонента в іiї структурі.

Виклад основного матеріалу дослідження. У зарубіжній і вітчизняній психолого-педагогічній науці останніми роками питання здатності вчителів закладів загальної освіти до впровадження інклюзивної освіти досліджується у декількох аспектах, передусім у контексті їх:

- інклюзивної культури - усвідомлення та прийняття вчителем цінностей індивідуальних потреб людини, рівних розвивальних та освітніх можливостей (N. Beacham, J. Corbett, M. Rouse, A. Watkins та ін.);

- інклюзивної компетентності - його часткової професійної компетентності, що зумовлює здатність вчителя здійснювати професійні функції в умовах інклюзивного освітнього простору (I. Хафізулліна, Т. П'ятакова, I. Демченко, Н. Рокосовик, В. Хітрюк, А. Колупаєва, О. Кузьміна, О. Таранченко та ін.);

- професійно-особистісної готовності до роботи в умовах інклюзивної освіти (О. Мартинчук, І. Возняк, Н. Чемекова та ін.) тощо.

Виходячи із проведеного нами у попередніх дослідженнях аналізу змісту понять «професійна культура педагога», «професійна компетентність педагога», «готовність педагога до професійної діяльності» у сучасній психолого-педагогічній науці, а також грунтуючись на положеннях авторського інтегративного підходу до розуміння сутності психолого-педагогічної компетентності викладача [2], зазначимо, що інклюзивна компетентність вчителя:

- по-перше, є видовим складником його цілісної професійної компетентності - складного особистісно-професійного утворення, особливої інтегративної якості, що забезпечує, з одного боку, ефективність професійної діяльності фахівця, успішне вирішення ним професійних завдань відповідно до актуальних нормативних вимог, а з іншого - рівновагу його особистісної та профе- сійної сфер, успішний особистісний та професійний розвиток;

- по-друге, є актуалізованою, реалізованою готовністю вчителя до виконання професійних функцій, тобто виявляється у реальній професійній діяльності фахівця, на відміну від професійної готовності до неї, що формується у процесі навчання, фахової підготовки майбутнього вчителя у закладах вищої освіти (в цьому вбачаємо методологічну різницю між інклюзивною компетентністю педагога та його готовністю (потенційною можливістю) до роботи в умовах інклюзивної освіти);

- по-третє, у своїй структурі містить діяльнісно-рольові (професійні знання і вміння) та суб'єктно-діяльнісні компоненти (індивідуально-психологічні властивості на всіх рівнях підсистем особистості (Б. Ананьєв, Н. Левітов, Б. Ломов, К. Платонов, С. Рубінштейн, Б. Теплов, В. Шадриков та ін.), що завдяки механізмам узагальнення, об'єктивізації та усвідомлення утворюють відповідні професійні якості вчителя);

- по-четверте, відображає основні вимоги суспільства до педагога як особистості і суб'єкта професійної діяльності, носія суспільно-історичного досвіду, й у цьому контексті поєднана 3 інклюзивною культурою (ціннісна складова частина інклюзивної компетентності вчителя по суті й об'єктивізує його інклюзивну культуру);

- по-п'яте, виявляється в діяльності і не може бути ізольованою від конкретних іiі умов: нові вимоги професійної педагогічної діяльності висувають нові вимоги до його інклюзивної компетентності, наповнення іiі складників, тому вона $€$ динамічною за своєю природою, перебуває у процесі постійного оновлення, розвитку.

Інклюзивна компетентність вчителя як системне утворення та особливе психічне явище в теоретичному аспекті виявляється у трьох виміpax як: 1) властивість; 2) процес; 3) стан людини-професіонала. Як інтегральна властивість вона $\epsilon$ результатом професіогенезу фахівця, презентує найбільш стійкі його особливості, що визначають певний якісно-кількісний рівень здійснення професійної діяльності. Як певний процес інклюзивна компетентність має фази/стадії свого розгортання: початок (становлення), перебіг (екстенсивний або інтенсивний розвиток, стагнацію, деградацію та ін.), завершення. Як певний стан педагога вона $\epsilon$ внутрішньо- та зовнішньо спостережуваною. Внутрішньо спостережуваний стан інклюзивної компетентності - це зафіксоване вчителем на певний момент інтегральне відчуття комфорту у процесі здійснення професійної діяльності; це гармонійність Я-професійного та Я-особистісного; це переживання задоволеності від результатів своєї педагогічної діяльності. Тоді як зовнішньо спостережуваний стан - це рівень її розвиненості, що 
визначається за зовнішніми ознаками, за результатами зовнішньої експертної оцінки - атестації, сертифікації, участі вчителя у професійних конкурсах, освітньо-професійних та освітньо-наукових програмах тощо, а також за результатами інституційного аудиту закладу освіти та ін.

Отже, інклюзивна компетентність сучасного вчителя є складовою частиною його цілісноїпрофесійної компетентності, складним особистісно-професійним утворенням, особливою інтегративною якістю, що забезпечує ефективність професійної діяльності фахівця із реалізації інклюзивного навчання, організації безпечного та здорового освітнього середовища, а також детермінує успішність його подальшого професійного розвитку загалом та у сфері інклюзивної освіти зокрема.

За своїм змістом інклюзивна компетентність учителя закладу загальної середньої освіти визначається крізь ті вимоги, що висуває педагогічна діяльність до нього у сучасних умовах розвитку вітчизняного суспільства.

Вимоги до інклюзивної компетентності вчителя закладів загальної середньої освіти в Україні натепер унормовані відповідним Професійним стандартом (2020), в якому однією із його трудових функцій визначена «участь в організації безпечного та здорового освітнього середовища» [9]. Так, згідно із затвердженим Професійним стандартом за професіями «Вчитель початкових класів закладів загальної середньої освіти», «Вчитель закладу загальної середньої освіти», «Вчитель 3 початкової освіти» (2020), інклюзивна компетентність складається із таких здатностей педагога, як: 1) здатність створювати умови, що забезпечують функціонування інклюзивного освітнього середовища; 2) здатність до педагогічної підтримки осіб 3 особливими освітніми потребами, 3) здатність забезпечувати в освітньому середовищі сприятливі умови для кожного учня залежно від його індивідуальних потреб, можливостей, здатностей та інтересів. Причому перша із здатностей забезпечується такими професійними знаннями, як знання інструментів забезпечення інклюзивного навчання (інклюзивна культура, інклюзивна політика, інклюзивна практика тощо) та принципів та стратегій універсального дизайну в сфері освіті та розумного пристосування, застосування яких визначають зміст відповідних професійних умінь [9].

Другаздатністьзабезпечується знаннями:принципів, форм та методів ефективної підтримки осіб 3 особливими освітніми потребами; видів адаптацій/модифікацій в освітньому процесі, зумовлених особливими освітніми потребами учнів, що своєю чергою визначають відповідні професійні уміння, а саме здійснення педагогічної підтримки осіб з особливими освітніми потребами, необхідні адаптації/модифікації освітнього процесу.
Третя здатність як складник інклюзивної компетентності вчителя грунтується на таких професійних знаннях, як знання: технологій індивідуального та диференційованого навчання; способів виявлення здібностей, інтересів, можливостей учнів; середовища як чинника розвитку особистості. Зазначені професійні знання знаходять своє практичне втілення у відповідних професійних уміннях: організовувати процеси навчання, виховання і розвитку учнів з урахуванням їхніх потреб, здібностей i реальних навчальних можливостей; використовувати в роботі з учнями матеріали, пристрої та обладнання для задоволення їхніх освітніх потреб; організовувати освітній простір безпечно таз урахуванням особливостей, потреб і можливостей учнів.

На жаль, у зазначеному вітчизняному нормативному документі вимоги до вчителів зафіксовані тільки на рівні професійних знань та вмінь i чітко не окреслюють базові характеристики їхніх цінностей, ставлень.

Зазначене протиріччя виявляється і у просторі наукових досліджень (С. Максимюк, М. Чайковський та ін.) та актуальної професійної підготовки вчителів - у змісті освітньо-професійних програм вищої та післядипломної педагогічної освіти, в яких акцент робиться на формуванні професійних знань та умінь фахівців.

В узагальненому для європейського освітнього простору документі, що презентує складники інклюзивної компетентності вчителя, - Профілі інклюзивних учителів (Teacher Education for Inclusion. Profile of inclusive teachers) [21], який складений за участю 55 експертів та більш ніж 400 інших зацікавлених осіб (учителів, керівників шкіл, батьків та ін.) 325 країн, зафіксовані як професійні знання та вміння, так і ті професійні цінності, що забезпечують успішну професійну діяльність педагогів у просторі інклюзивної освіти. Причому у документі зафіксовано, що вихідними, системоутворювальними для зазначених у Профілі вимог/компетентностей до вчителів $\epsilon$ такі основні цінності, як-то: 1) цінування різноманітності учнів - різниця між учнями розглядається як ресурс та як актив для освіти; 2) підтримка всіх учнів - вчителі покладають великі очікування щодо досягнень усіх учнів; 3) робота 3 іншими - співпраця та робота в команді є важливими підходами для всіх; 4) постійний особистий професійний розвиток - викладання $є$ навчальною діяльністю і вчителі несуть відповідальність за власне навчання впродовж життя. Саме ці чотири групи цінностей, які не є ієрархічно побудованими, а є рівноцінними, і визначають, згідно iз зазначеним рамковим документом, провідні професійні ставлення, знання та уміння вчителів щодо інклюзивного навчання, які й утворюють цілісну інклюзивну компетентність. У зарубіжній 
освітній практиці існує також і досвід цілеспрямованого первинного відбору педагогів до роботи в інклюзивному освітньому середовищі, критерієм якого $є$ саме ціннісний компонент їх професійної компетентності $[16 ; 18 ; 20]$ - прийняття цінностей філософії інклюзії.

Отже, на наш погляд, украй важливим для розбудови інклюзивного освітнього середовища у вітчизняних закладах освіти $є$ зміщення акценту на першочергове формування ціннісного компонента інклюзивної компетентності вчителів. Адже саме ціннісний компонент «запускає» професійну діяльність та професійний розвиток особистості загалом та педагога зокрема; саме професійні ставлення віддзеркалюють не нав'язаний із зовні, a прийнятий, згідно 3 внутрішніми мотивами, iii вибір. Професійні ставлення відображаються через дії педагога, спонукають професійну поведінку. Вони відбиваються в єдності мотиваційного (переживання потреби), афективного (емоційні переживання), когнітивного (усвідомлення дійсності, певна розстановка акцентів у пізнавальних процесах, в їх спрямованості та активності) та поведінкового (відбір та актуалізація способів поведінки) компонентів (О. Бодальов [1]). I саме ціннісне ставлення як найвищий рівень ставлення вчителя, що $є$ усвідомленим, стійким та супроводжується емоційним переживанням, і виступає регулятором його професійної компетентності, професійної діяльності та професійного розвитку.

Таким чином, саме ціннісне ставлення вчителів до інклюзивної освіти є одним 3 найголовніших чинників іiі успішної реалізації, воно визначає глибину та дієвість професійних знань, оперативність професійних умінь, актуалізованість професійних якостей.

Отже, досліджуючи структуру інклюзивної компетентності вчителя з урахуванням положення інтегративного підходу до професійної компетентності педагога [2] та Рекомендації ради Європи щодо ключових компетентностей для освіти впродовж життя (2018), насамперед важливо зосереджуватися на її ціннісному компоненті, що є системотвірним, інтегрувальним, методологічним та містить: прийняття педагогом цінностей філософії інклюзивної освіти; прийняття власної інклюзивності, зумовленої усвідомленням особистої унікальності, неповторності та, відповідно, наявності особливих освітніх потреб; ціннісне ставлення до інклюзивного навчання, до проєктування та організації інклюзивного освітнього середовища; прийняття ролі фасилітатора, проєктувальника індивідуальної освітньої траєкторії учнів; позитивну мотивацію педагогічної діяльності та професійного розвитку, а також позитивне ставлення до необхідності зміни власної педагогічної діяльності, застосування нових освітніх стратегій.
Саме ціннісний компонент актуалізує інші компоненти інклюзивної компетентності вчителя, a саме: когнітивний як систему теоретичних та методичних знань у сфері інклюзивної освіти: сутності інклюзивної освіти (принципів, змісту, форм і методів тощо), іiі специфічних відмінностей від інших освітніх форм; особливостей розвитку (фізичного, психічного, психологічного та соціального) учнів, закономірностей вікового й особистісного розвитку дітей з особливими освітніми потребами різних груп; принципів, методів організації інклюзивного освітнього середовища; методів психологічного та дидактичного проєктування навчального процесу для спільного навчання дітей тощо; та конструктивний як систему його гностичних, проєктувальних, організаційних, комунікативних, конструктивних, дослідницьких, фасилітативних та рефлексивних професійних умінь.

Отримані результати здійсненого Обласним науково-методичним центром психології та соціології освіти Запорізького обласного інституту післядипломної педагогічної освіти соціально-психологічного дослідження «Визначення рівня задоволеності основних суб'єктів освітнього процесу щодо запровадження інклюзивного навчання в закладах освіти Запорізької області» (2019) за участю педагогів, батьків та учнів 32 регіональних закладів загальної середньої освіти яскраво засвідчують гостру необхідність у цілеспрямованому формуванні ціннісного ставлення вчителів до інклюзивної освіти через усвідомлення та прийняття ними світових цінностей інклюзії, не обмежених потребами дітей з порушеннями психофізичного розвитку. Адже тільки $46,7 \%$ опитаних учителів $2-3$ класів та $52,3 \%$ учителів 6-7 класів з інклюзивною формою навчання повністю підтримують ідеологію інклюзивного навчання. Підтримують лише за умови рівності прав усіх дітей 44,4\% учителів $2-3$ класів та $47,6 \%$ учителів 6-7 класів. Крім того, більшість опитаних учителів 6-7 класів $(61,9 \%)$ негативно оцінюють вплив інклюзивного навчання на особистісний розвиток учнів у класі. Отже, зазначені дані опитування свідчать про фокусування заходів із розбудови інклюзивного освітнього середовища у цих закладах освіти на освітніх потребах однієї групи учнів - 3 порушеннями психофізичного розвитку, що і призводить до неприйняття значною частиною вчителів цінностей інклюзивної освіти, недовіри до іï ефективності.

Недостатнє усвідомлення вчителями цінностей інклюзивної освіти підтверджується і результатами опитування учнів 6-7 класів щодо ставлення до них учителів. Так, якщо, на думку учнів 3 порушеннями психофізичного розвитку, більшість учителів ставляться до них доброзичливо (85\% опи- 
таних), поважливо (55\%), намагаються своєчасно допомагати (88\%), підбадьорюють (52\%) та вчать інших допомагати $(45 \%)$, то більшість опитаних учнів 6-7 класів без порушень психофізичного розвитку ставлення до них учителів визначають менш позитивно. Тільки 16\% учнів 6-7 класів зазначили про те, що навчання відбувається з урахуванням їхніх індивідуальних особливостей, а вчителі не виокремлюють i не протиставляють їх іншим, ставляться до всіх у класі однаково. Отримані дані яскраво свідчать про звужене до однієї категорії учнів розуміння вчителями сутності інклюзивного навчання, фокусування педагогічної підтримки у закладі загальної середньої освіти лише на рівні спеціальної підтримки (окремих учнів у класі) у разі відсутності іiі базових рівнів - загальної та посиленої. Це ще раз доводить те, що успішне інклюзивне навчання - це, передусім, професійне викладання, успішна педагогічна практика [17], а ніяк не якісь особливі педагогічні стратегії.

Висновки. Інклюзивна компетентність сучасного вчителя закладу загальної середньої освіти $\epsilon$ складником його цілісної професійної компетентності, підкоряється принципам іï структурної організації та закономірностям розвитку. Як складне особистісно-професійне утворення особлива інтегративна якість, що забезпечує ефективність професійної діяльності фахівця із реалізації інклюзивного навчання, організації безпечного та здорового освітнього середовища, а також детермінує успішність його подальшого професійного розвитку загалом та у сфері інклюзивної освіти зокрема, вона складається 3 трьох компонентів - ціннісного, когнітивного та конструктивного. Саме ціннісний компонент інклюзивної компетентності є системотвірним, інтегрувальним, методологічним; він актуалізує професійні знання та вміння вчителя, «запускає» його професійну діяльність та професійний розвиток.

Формування інклюзивної компетентності вчителя 3 урахуванням ii багатокомпонентної, динамічної структури $є$ складним i тривалим процесом, що вимагає комплексності та різновекторності дій. Традиційне спрямування педагогічної освіти на оволодіння вчителями спеціалізованими професійними знаннями та уміннями для розбудови інклюзивного освітнього середовища має бути переорієнтоване на забезпечення формування у вчителів ціннісного ставлення до інклюзіі як створення умов для повноцінної участі та доступу до якісних навчальних можливостей всіх учнів відповідно до їхніх індивідуальних особливостей. Це досягається завдяки актуалізації у процесі вищої та післядипломної педагогічної освіти базового механізму формування ціннісного ставлення (за В. Мясищевим, Д. Леонтьєвим), що передбачає цілеспрямоване створення умов для: a) переживання вчителями потреби у реалізації інклюзивного підходу в освіті завдяки: актуалізації особистісного досвіду, оживленню знань та ін.; б) нового освоєння (усвідомлення) сутності інклюзії, методологічних засад, принципів та стратегії інклюзивного навчання завдяки проблематизації, розхитуванню наявних стереотипів, установок, рефлексивним стратегіям тощо; в) створення та реалізації об'єктивної цінності інклюзії; та, нарешті, г) трансформування об'єктивної цінності у суб' єктивну, що досягається завдяки інтеріоризації смислів діяльності в умовах супервізії, інтервізії та ін. форм психолого-педагогічного супроводу розвитку професійної компетентності вчителів.

\section{ЛІТЕРАТУРА}

1. Бодалев А.А. Психология о личности. Москва : Изд-во Моск. ун-та, 1988. 188 с.

2. Гура О.І. Психолого-педагогічна компетентність викладача вищого навчального закладу: теоретикометодологічний аспект : монографія. Запоріжжя : ГУ «ЗІДМУ», 2006. 332 с.

3. Дослідження якості інклюзивного навчання для дітей з особливими освітніми потребами. URL: https://mon.gov.ua/storage/app/media/inkluzyvne-navchannya/2021/04/02/Doslidzhennya_yakosti_ inklyuzyvnoyi_osvity_1_02_04.pdf (дата звернення: 16.07.2021).

4. Доступ дітей 3 особливими освітніми потребами до інклюзивної освіти у Львівській області: звіт за результатами дослідження. Київ. 2021. 80 с.

5. Закон України «Про освіту». URL: https://zakon.rada.gov.ua/laws/show/2145-19 (дата звернення: 16.07.2021).

6. Колупаєва А.А., Таранченко О.М. Інклюзивна освіта: від основ до практики : монографія. Київ : ТОВ «АТОПОЛ», 2016. $152 \mathrm{c}$.

7. Леонтьев Д.А. Психология смысла. Природа, строение и динамика смысловой реальности. Москва : Смысл, 2003. 488 с.

8. Мясищев В.Н. Психология отношений. Москва : МПСИ, 2005. 158 с.

9. Наказ Мінекономіки від 23.12.20 № 2736 «Про затвердження Професійного стандарту за професіями «Вчитель початкових класів закладу загальної середньої освіти», «Вчитель закладу загальної середньої освіти». URL: https://zakon.rada.gov.ua/rada/show/v2736915-20\#Tехt (дата звернення: 16.07.2021). 
10. Нова українська школа : порадник для вчителя / Під заг. ред. Бібік Н.М. Київ : ТОВ «Видавничий дім «Плеяди», 2017. 206 с.

11. Постанова Кабміну України від 21 серпня 2013 р. № 607 «Про затвердження Державного стандарту початкової загальної освіти для дітей з особливими освітніми потребами». URL: https://zakon.rada. gov.ua/laws/show/607-2013-\%D0\%BF\#Text (дата звернення: 16.07.2021).

12. Розвиток інклюзивного освітнього середовища в Запорізькій області: науково-методичний аспект : монографія / упор. Т.Є. Гура; ред. Т.Я. Озерова. Запоріжжя : СТАТУС, 2018. 328 с.

13. Розпорядження Кабміну «Про схвалення Концепції реалізації державної політики у сфері реформування загальної середньої освіти «Нова українська школа» на період до 2029 року». URL: https://zakon.rada.gov.ua/laws/show/988-2016-\%D1\%80\#Text (дата звернення: 16.07.2021).

14. Цимбал-Слатвінська С. Класифікація дітей з особливими освітніми потребами в аспекті професійної діяльності логопеда. Психолого-педагогічні проблеми сучасної школи. Збірник наукових прачь. 2019. Вип. 2. URL: http://ppsh.udpu.edu.ua/article/view/178478 (дата звернення: 16.07.2021).

15. Ashby C. Disability Studies and Inclusive Teacher Preparation: A Socially Just Path for Teacher Education. Two perspectives on Inclusion in the United States. Research and Practice for Persons with Severe Disabilities, 2012. 37(2), pp. 89-99.

16. Beacham N., Rouse M. Student teachers' attitudes and beliefs about inclusion and inclusive practice. Journal of Research in Special Educational Needs, 2012. 12, pp. 3-11.

17. Hattie J. Visible Learning: A Synthesis of Over 800 Meta-Analyses Relating to Achievement. 2012. URL: https://www.researchgate.net/publication/270585193_Visible_Learning_A_Synthesis_of_Over_800_ Meta-Analyses_Relating_to_Achievement (дата звернення: 16.07.2021)

18. Levins T., Bornholt L., Lennon B. Teachers' experience, attitudes, feelings and behavioural intentions towards children with special educational needs. Social Psychology of Education, 2005. 8, pp. 329-343.

19. On the road to inclusion. UNESCO. 2019. URL: https://unesdoc.unesco.org/ark:/48223/pf0000370910 (дата звернення: 16.07.2021).

20. Pit-ten Cate I.M., Markova M., Krischler M., Krolak-Schwerdt S. Promoting Inclusive Education: The Role of Teachers' Competence and Attitudes. Insights into Learning Disabilities, 2018. 15(1), pp. 49-63.

21. Teacher Education for Inclusion. Profile of inclusive teachers. URL: https://www.european-agency.org/ sites/default/files/Profile-of-Inclusive-Teachers.pdf (дата звернення: 16.07.2021).

\section{REFERENCES}

1. Bodalev, A.A. (1988). Psikhologiya o lichnosti. Moskva: Izd-vo Mosk. un-ta [in Russian].

2. Gura, O.I. (2006). Psykhologho-pedaghoghichna kompetentnistj vykladacha vyshhogho navchaljnogho zakladu: teoretyko-metodologhichnyj aspekt: monoghrafija. Zaporizhzhja: GhU “ZIDMU” [in Ukrainian].

3. Doslidzhennja jakosti inkljuzyvnogho navchannja dlja ditej z osoblyvymy osvitnimy potrebamy. Retrieved from: https://mon.gov.ua/storage/app/media/inkluzyvne-navchannya/2021/04/02/Doslidzhennya_yakosti_inklyuzyvnoyi_osvity_1_02_04.pdf (accessed: 16.07.2021) [in Ukrainian].

4. Dostup ditej z osoblyvymy osvitnimy potrebamy do inkljuzyvnoji osvity u Ljvivsjkij oblasti: zvit za rezuljtatamy doslidzhennja. (2021) Kyiv [in Ukrainian].

5. Zakon Ukrajiny "Pro osvitu". Retrieved from: https://zakon.rada.gov.ua/laws/show/2145-19 (accessed: 16.07.2021) [in Ukrainian].

6. Kolupajeva, A.A., Taranchenko, O.M. (2016). Inkljuzyvna osvita: vid osnov do praktyky: monoghrafija. Kyiv: TOV "ATOPOL" [in Ukrainian].

7. Leont'ev, D.A. (2003). Psikhologiya smysla. Priroda, stroenie i dinamika smyslovoy real'nosti. Moskva: Smysl [in Russian].

8. Myasishchev, V.N. (2005). Psikhologiya otnosheniy. Moskva: MPSI [in Russian].

9. Nakaz Minekonomiky vid 23.12.20 No. 2736 "Pro zatverdzhennja Profesijnogho standartu za profesijamy "Vchytelj pochatkovykh klasiv zakladu zaghaljnoji serednjoji osvity", "Vchytelj zakladu zaghaljnoji serednjoji osvity". Retrieved from: https://zakon.rada.gov.ua/rada/show/v2736915-20\#Text (accessed: 16.07.2021) [in Ukrainian].

10. Nova ukrajinsjka shkola: poradnyk dlja vchytelja. (2017). Kyiv: TOV "Vydavnychyj dim "Plejady" [in Ukrainian].

11. Postanova Kabminu Ukrajiny vid 21 serpnja 2013 r. No. 607 "Pro zatverdzhennja Derzhavnogho standartu pochatkovoji zaghaljnoji osvity dlja ditej z osoblyvymy osvitnimy potrebamy". Retrieved from: https://zakon.rada.gov.ua/laws/show/607-2013-\%D0\%BF\#Text (accessed: 16.07.2021) [in Ukrainian].

12. Rozvytok inkljuzyvnogho osvitnjogho seredovyshha $\mathrm{v}$ Zaporizjkij oblasti: naukovo-metodychnyj aspekt: monoghrafija. (2018). Zaporizhzhja: STATUS [in Ukrainian]. 
13. Rozporjadzhennja Kabminu "Pro skhvalennja Koncepciji realizaciji derzhavnoji polityky u sferi reformuvannja zaghaljnoji serednjoji osvity "Nova ukrajinsjka shkola" na period do 2029 roku". Retrieved from: https://zakon.rada.gov.ua/laws/show/988-2016-\%D1\%80\#Text (accessed: 16.07.2021) [in Ukrainian].

14. Cymbal-Slatvinsjka, S. (2019). Klasyfikacija ditej z osoblyvymy osvitnimy potrebamy v aspekti profesijnoji dijaljnosti loghopeda. Psykhologho-pedaghoghichni problemy suchasnoji shkoly. Zbirnyk naukovykh pracj. Vyp. 2. Retrieved from: http://ppsh.udpu.edu.ua/article/view/178478 (accessed: 16.07.2021) [in Ukrainian]

15. Ashby, C. (2012). Disability Studies and Inclusive Teacher Preparation: A Socially Just Path for Teacher Education. Two perspectives on Inclusion in the United States. Research and Practice for Persons with Severe Disabilities, 37(2), pp. 89-99.

16. Beacham, N., Rouse, M. (2012). Student teachers' attitudes and beliefs about inclusion and inclusive practice. Journal of Research in Special Educational Needs, 12, pp. 3-11.

17. Hattie, J. (2012). Visible Learning: A Synthesis of Over 800 Meta-Analyses Relating to Achievement. Retrieved from: https://www.researchgate.net/publication/270585193_Visible_Learning_A_Synthesis_ of_Over_800_Meta-Analyses_Relating_to_Achievement (accessed: 16.07.2021).

18. Levins, T., Bornholt, L., Lennon, B. (2005). Teachers' experience, attitudes, feelings and behavioural intentions towards children with special educational needs. Social Psychology of Education, 8, pp. 329-343.

19. On the road to inclusion. UNESCO. 2019. Retrieved from: https://unesdoc.unesco.org/ark:/48223/ pf0000370910 (accessed: 16.07.2021).

20. Pit-ten Cate, I.M., Markova, M., Krischler, M., Krolak-Schwerdt, S. (2018). Promoting Inclusive Education: The Role of Teachers' Competence and Attitudes. Insights into Learning Disabilities, 15(1), pp. 49-63.

21. Teacher Education for Inclusion. Profile of inclusive teachers. Retrieved from: https://www.european-agency.org/sites/default/files/Profile-of-Inclusive-Teachers.pdf (accessed: 16.07.2021). 